\title{
Exposure to risk factors for Hepatitis B and C viruses among primary school teachers in Karachi
}

\author{
Muhammad Ayaz Mustufa, Ashfque Ahmed Memon, Sadia Nasim, Anjum Shahid, Sobiya Mohiuddin \\ Omar
}

PMRC Specialized Research Center, National Institute of Child Health (NICH), Karachi, Pakistan

\begin{abstract}
Introduction: The study aimed to determine hepatitis B vaccination status and assess the exposure of risk factors for hepatitis B and C among primary schoolteachers in Karachi, Pakistan.

Methodology: in Two hundred school teachers from 30 primary schools in Karachi participated in the study between January and June 2008 by completing an anonymous, self-administered questionnaire. Exposure to and knowledge of hepatitis B and C were assessed, as well as mode of transmission and prevention. The percentage of vaccinated and non-vaccinated teachers was also estimated.

Results: Only $73(36.5 \%)$ respondents were vaccinated against HBV. Nine percent (17) of the teachers had received more than 10 therapeutic injections while about 56\% (101) took between 5-10 injections per annum. Fifteen (8\%) of the teachers confirmed they had been injected with re-used syringes. More than 8\% (17) of participants' family members were suffering from hepatitis B or C, while 10\% (20) of family members had died of liver diseases without any known history. More than 13\% (27) of participants shared razors, brushes, cigarettes and hukahs. Statistically significant difference was also observed in risk factors of hepatitis B and C among male and female respondents. Conclusion: Hepatitis B vaccination among school teachers of Karachi was around 37\% with a high use of therapeutic injections and syringe reuse. Health awareness programs and educational workshops are needed for teachers, who can later educate the children.
\end{abstract}

Key words: school teachers, hepatitis, vaccination

J Infect Dev Ctries 2010; 4(10):616-620.

(Received 11 November 2009 - Accepted 15 May 2010)

Copyright ( 92010 Mustufa et al. This is an open-access article distributed under the Creative Commons Attribution License, which permits unrestricted use, distribution, and reproduction in any medium, provided the original work is properly cited.

\section{Introduction}

Viral hepatitis is a major public health problem in all parts of the world [1]. It is a significant cause of morbidity and mortality, especially in developing countries. An estimated 350 million people worldwide are chronic HBV carriers, representing approximately $7 \%$ of the total population [2,3], and it causes one million deaths annually [4]. Pakistan is in the intermediate $\mathrm{HBV}$ prevalence area with a carrier rate of 3-4\% [5]. Chronic hepatitis $\mathrm{B}$ is a severe problem in Pakistan [6]. In a community-based study $31 \%$ percent of the individuals tested had hepatitis $\mathrm{B}$ core antibodies and $4.3 \%$ had hepatitis B surface antigen [7]. Hepatitis $\mathrm{C}$ virus (HCV) is the major cause of transfusion associated non-A, non-B hepatitis and continues to be a major cause of human liver disease throughout the world. HCV infection is found in approximately $3 \%$ of the world's population, accounting for 160 million people $[8,9]$. The burden of HCV-related chronic liver disease in Pakistan has increased. It has been demonstrated that nearly $50 \%$ patients with hepatocellular carcinoma in Pakistan are anti-HCV positive [10]. As HBV and hepatitis $\mathrm{C}$ virus (HCV) have the same transmission routes, dual infection may occur. Patients co-infected with both HBV and HCV may have more severe liver disease and high mortality rate $(10 \%)$ [11,12].

Knowledge of the causes and risk factors for $\mathrm{HBV}$ and $\mathrm{HCV}$ is of utmost importance in preventing the spread of these diseases. Since primary schoolteachers are in an excellent position to pass this information to the upcoming generations, this study assessed the exposure of primary schoolteachers in Karachi to hepatitis B and C and their hepatitis B vaccination status.

\section{Methodology}

The study was conducted in 30 randomly selected primary schools in Karachi from January to June 2008. Two hundred schoolteachers, representing 15 public and 15 private schools, participated in the study after giving informed verbal consent. 
Table 1. Demographic features.

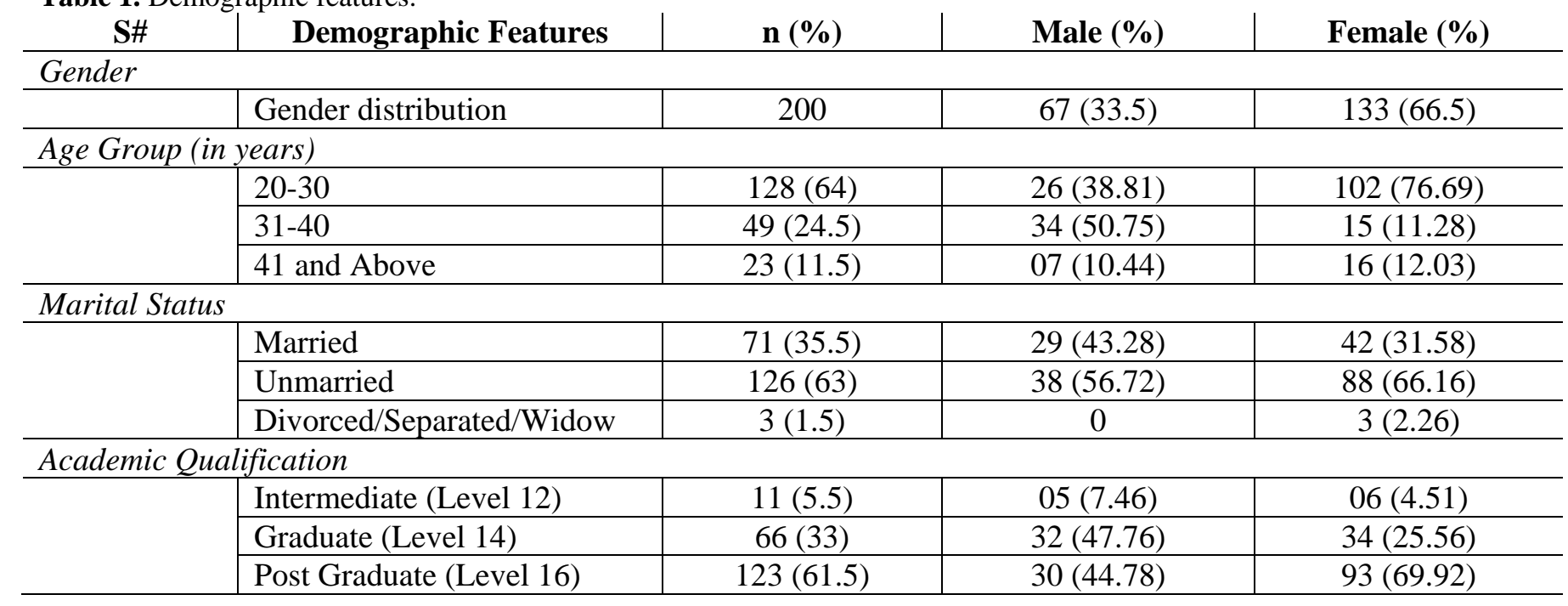

After getting formal permission from the head of school to approach the teachers, specially trained research team members explained the purpose and objectives of the study to the faculty and obtained written informed consent from every individual before administering the questionnaire. The research team administered a pre-tested questionnaire to the teachers to obtain information on socio-demography and potential risk factors for $\mathrm{HCV}$ and $\mathrm{HBV}$ transmission. The questions gathered the following information: age; gender; socio-economic status; educational level in years; number of injections used per annum; vaccination status; history of surgical procedures and/or blood products transfusion; factors predisposing to the horizontal transmission of hepatitis B; history or current use of intravenous drugs of the participant and of siblings or other family members; history of tattooing or ear piercing; jaundice or diagnosis of HCV or HBV among participants, siblings, parents, or other family members (Table 1).

The data was analyzed using Statistical Package for Social Sciences (SPSS) version 10.0. The analysis was conducted and descriptive statistics of sociodemographic variables and other characteristics of the sample population were computed. Mean, ratio and percentages were calculated for quantitative variables and P-value was used to calculate statistically significant differences.

\section{Results}

As highlighted in Figure I, only $36.5 \cong 37 \%$ (73) primary schoolteachers in this study were found hepatitis B vaccinated. More than 62\% (83) of the female teachers and around $66 \%$ (44) of the male teachers were not hepatitis $\mathrm{B}$ vaccinated. Table 1 shows that the majority of respondents were female, with a ratio of $2: 1$. The study participants ranged in age from 19 to 57 years, and more than half of them (64\%) were young, between the ages of 20 and 30 years. Out of a total of 71 married respondents, 42 were females and 29 were males. More than $61 \%$ of the primary schoolteachers were postgraduates, mostly in arts subjects.

Figure 1. Hepatitis B vaccination status in Primary school teachers of Karachi.

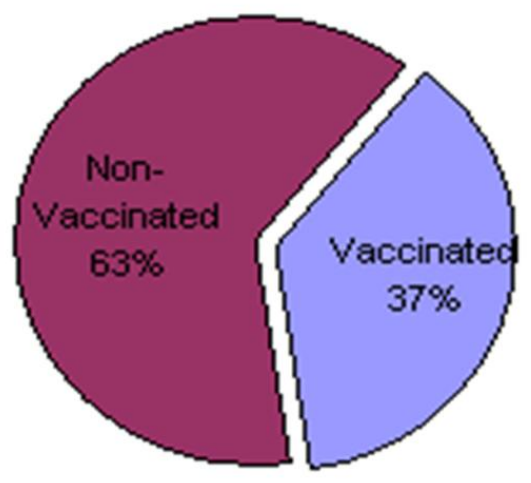

Data on exposure to risk factors of hepatitis B and $\mathrm{C}$ among the primary schoolteachers in our study is presented in Table 2. Out of 200 respondents, 180 $(90 \%)$ were using therapeutic injections. Around $97 \%$ of the male teachers and $86 \%$ of the female teachers indicated the common use of therapeutic injections. 
Table 2. Exposure to Risk Factors of Hepatitis Band C among Primary School Teachers

\begin{tabular}{|c|c|c|c|c|c|}
\hline S\# & Associated Risk Factors & $\begin{array}{c}\mathrm{n}(\%) \\
\text { Total subjects }=\mathbf{2 0 0}\end{array}$ & $\begin{array}{c}\text { Male }(\%) \\
(n=67)\end{array}$ & $\begin{array}{l}\text { Female }(\%) \\
(n=133)\end{array}$ & P- value \\
\hline \multicolumn{6}{|c|}{ Ever have/had jaundice } \\
\hline & $\begin{array}{l}\text { Yes } \\
\text { No }\end{array}$ & $\begin{array}{c}61(30.5) \\
139(69.5)\end{array}$ & $\begin{array}{l}23(34.33) \\
44(65.67)\end{array}$ & $\begin{array}{l}38(28.57) \\
95(71.43)\end{array}$ & .50 \\
\hline
\end{tabular}

Any family member suffering in Hepatitis Band C

\begin{tabular}{l|c|c|c|c} 
Yes & $17(8.5)$ & $6(8.96)$ & $11(8.27)$ & .9 \\
No & $183(91.5)$ & $61(91.04)$ & $122(91.73)$ & \\
\hline
\end{tabular}

Family member died due to Hepatitis Band $C$

\begin{tabular}{|c|c|c|c|c|c|}
\hline & $\begin{array}{l}\text { Yes } \\
\text { No }\end{array}$ & $\begin{array}{c}16(8) \\
184(92) \\
\end{array}$ & $\begin{array}{c}03(4.48) \\
64(95.52) \\
\end{array}$ & $\begin{array}{c}13(9.77) \\
120(90.23) \\
\end{array}$ & .30 \\
\hline \multicolumn{6}{|c|}{ Family member died due to liver disease } \\
\hline & $\begin{array}{l}\text { Yes } \\
\text { No }\end{array}$ & $\begin{array}{c}20(10) \\
180(90)\end{array}$ & $\begin{array}{c}4(5.97) \\
63(94.03)\end{array}$ & $\begin{array}{c}16(4.51) \\
117(95.49)\end{array}$ & .27 \\
\hline \multicolumn{6}{|c|}{ History of surgery/hospitalization/Dental treatment } \\
\hline & $\begin{array}{l}\text { Yes } \\
\text { No }\end{array}$ & $\begin{array}{c}24(12) \\
176(88)\end{array}$ & $\begin{array}{c}2(2.99) \\
65(97.01)\end{array}$ & $\begin{array}{c}22(16.54) \\
111(83.46)\end{array}$ & $* .01$ \\
\hline \multicolumn{6}{|c|}{ Use of Syringes } \\
\hline & $\begin{array}{l}\text { Yes } \\
\text { No }\end{array}$ & $\begin{array}{c}180(90) \\
20(10)\end{array}$ & $\begin{array}{c}65(97.01) \\
2(2.99)\end{array}$ & $\begin{array}{c}115(86.47) \\
18(13.53)\end{array}$ & $* .03$ \\
\hline \multicolumn{6}{|c|}{ Use of reuse syringes } \\
\hline & $\begin{array}{l}\text { Yes } \\
\text { No }\end{array}$ & $\begin{array}{c}15(8.33) \\
165(91.67)\end{array}$ & $\begin{array}{c}3(4.62) \\
62(95.38)\end{array}$ & $\begin{array}{c}12(10.43) \\
103(89.57)\end{array}$ & .28 \\
\hline \multicolumn{6}{|c|}{ No. of injections per annum } \\
\hline \multicolumn{6}{|c|}{ Visit to barber shop/ beauty parlor } \\
\hline & $\begin{array}{l}\text { Yes } \\
\text { No }\end{array}$ & $\begin{array}{c}97(43.5) \\
103(51.5)\end{array}$ & $\begin{array}{c}65(97.01) \\
2(2.99)\end{array}$ & $\begin{array}{c}32(24.10) \\
101(75.90)\end{array}$ & $* .001$ \\
\hline \multicolumn{6}{|c|}{ Ever had tattooing/acupuncture } \\
\hline & $\begin{array}{l}\text { Yes } \\
\text { No }\end{array}$ & $\begin{array}{c}7(3.5) \\
193(96.5)\end{array}$ & $\begin{array}{c}6(8.96) \\
61(91.04)\end{array}$ & $\begin{array}{c}1(0.75) \\
132(99.25)\end{array}$ & $* .01$ \\
\hline \multicolumn{6}{|c|}{ Sharing of various items (Tooth Brush, Hukaah, Miswak, Blades, Vax,etc) } \\
\hline
\end{tabular}

* = Statistically significant, $(\mathrm{P}<0.05)$

Almost 9\% (17) teachers had a history of more than 10 therapeutic injections per annum, while about $56 \%$ (101) received 5 to 10 injections per annum. More than $8 \%$ (15) of the teachers confirmed that they had been injected with re-used syringes. More than $8 \%$ (17) also reported having family members who were suffering from hepatitis $\mathrm{B}$ or $\mathrm{C}$, while $8 \%$ (16) of the respondents stated that they had family members who died from either hepatitis B or C. Twenty $(10 \%)$ of the respondents' family members died from liver diseases without any known history. Use of tattooing or acupuncture was also found in
$3.5 \%$ of the respondents, particularly in the males. More than $13 \%$ (27) of the respondents were aware of the risks of clued up about sharing their razors, brushes, cigarettes, and hukahs. At large, male participants were significantly $(\mathrm{P}<.05)$ more exposed to risks such as the use of therapeutic syringes $(97 \%)$, sharing of various items $(28.4 \%)$, tattooing/acupuncture $(9 \%)$ and visits to a barber shop/beauty parlor (44\%) than the females, while excessive hospitalization/surgical procedures/dental treatments $(17 \%)$ were more common risk factors of hepatitis $\mathrm{B}$ and $\mathrm{C}$ in the female respondents. 


\section{Discussion}

In our study, hepatitis B vaccination among primary school teachers of Karachi was around 37\%, which is very low, even though vaccination for HBV is part of the routine Expanded Program on Immunization (EPI) that was launched in a nationwide vaccination campaign with the help of Global Alliance for Vaccines and Immunization (GAVI) in 2004 [13-14].

The current study has some limitations. First, the sample size was unavoidably low. Second, we did not include hepatitis $\mathrm{B}$ and $\mathrm{C}$ core antibody and liver function tests as doing so would have increased the costs. However, our findings provide essential information that highlights the need to strengthen the awareness program of hepatitis $\mathrm{B}$ and $\mathrm{C}$ as well as the necessity of educating the population on the risks of the disease. Risk assessment should be undertaken through surveillance and proper documentation to introduce and establish the actual level of exposure present within the community.

Use of syringes was found in $90 \%$ of the respondents. Out of these, more than $55 \%$ received 5 to 10 syringe injections per annum and around $10 \%$ were received more than 10 syringe injections per annum. The meta-analysis of previous studies supported that subjects who received more injections were more likely to be infected [5,7,14-16]. Overall, more than $65 \%$ of the primary schoolteachers were found to be at a high risk of infection due to high use of therapeutic injections.

There was a significant difference observed in male and female teachers with respect to their exposure to certain risk factors. Male teachers were more exposed to risks associated with the use of therapeutic syringes, tattooing, visits to the barber shop, and the sharing of various items including hukahs, cigarettes, razors, etc. Female teachers, on the other hand, were comparatively more vulnerable to $\mathrm{HBV}$ and $\mathrm{HCV}$ infection from excessive hospitalization and surgical procedures, mainly due to the delivery of babies of pregnant females and from dental treatment.

Another very alarming finding in both male and female primary schoolteachers was that more than $7 \%$ of the teachers in our study confirmed that they had been injected with previously used syringes. This fact shows the high level of unawareness and negligence even in the educated community of the city regarding risk factors of hepatitis $\mathrm{B}$ and $\mathrm{C}$.

The risk of $\mathrm{HBV}$ and $\mathrm{HCV}$ transmission among primary schoolteachers of Karachi does not appear to be different from that in the general population. It is important to note that many schoolteachers in our study are at an increased risk of HBV and HCV virus cross-transmission from the high use of syringe injections and dental treatment, as well as from the presence of and contact with $\mathrm{HBV}$ and $\mathrm{HCV}$ positive cases at their homes or in their families. In this situation, all teachers need to be vaccinated immediately to prevent infection from exposure to blood or body fluids.

In conclusion, immunization coverage of hepatitis B in primary schoolteachers is around $37 \%$, suggesting low coverage of hepatitis $B$ vaccination and high exposure to risk factors for hepatitis B and C. We recommend rapid, increased immunization against hepatitis B to help prevent its spread. Furthermore, health awareness programs and educational workshops need to be implemented for teachers who can then later educate the children.

\section{References}

1. Kao JH, Chen PJ, Lai MY, Chen DS (2002) Occult hepatitis $B$ virus infection and clinical outcomes of patients with chronic hepatitis C. J Clin Microbiol 40: 4068-4071.

2. Colin WS, Edgar PS, Lyn F (2006) Hepatitis B Virus Infection: Epidemiology and Vaccination. Epidemiologic Reviews 28: 112-125

3. Zaki H, Darmstadt GL, Baten A, Ahsan CR, Saha SK ( 2003) Seroepidemiology ofhepatitis B and dalta virus infection in Bangladesh. J Trop Pediatr 49: 371-374.

4. Mahoney FJ (1999) Update on diagnosis, management and prevention of hepatitis virus infection.Clin. Microbiol Rev 12: $351-366$.

5. Andre F (2000) Hepatitis B epidemiology in Asia: the Middle East and Africa. Vaccine 18 Suppl 1: S20-S22.

6. Khan AA, Rehman KU, Haider Z, Shafqat F (2002) Seromarkers of hepatitis B and $\mathrm{C}$ in patients with cirrhosis. J Coll Phys Surg Pak 12: 105-107.

7. Luby SP, Qamruddin K, Shah AA (1997) The relationship between therapeutic injections and high prevalence of hepatitis $\mathrm{C}$ infection in Hafizabad, Pakistan. Epidemiol Infect 119: 349-356.

8. Zou S, Tepper M, Giulivi A (2000) Current status of hepatitis C in Canada. Can J Public Health 91: S10-S16.

9. Arora DR, Sehgal R, Gupta N, Yadav A, Mishra N, Siwach SB (2005) Prevalence of parenterally transmitted hepatitis viruses in clinically diagnosed cases of hepatitis. Indian Journal of Medical Microbiology 23: 44-47.

10. Chohan AR, Umar M, Khaar B, Khurram M, Zahid M, Shah SF, Anwar F, Nasir S, Iqbal R, Shahzad M, Ansari M (2001) Demographic features of hepatocellular carcinoma. A study of 30 cases. J Rawal Med Coll 5: 81-83.

11. Mohamed AS, al Karawi MA, Mesa GA (1997) Dual infection with hepatitis C and B viruses: Clinical and histological study in Saudi patients. J Hepatogastroenterology 44: 1404-1406.

12. Perumalswami PV and Bini EJ (2006) Epidemiology, natural history and treatment of hepatitis B virus and 
hepatitis $\mathrm{C}$ virus coinfection. Minerva Gastroenterol Dietol 52: 145-155.

13. Ministry of Health (2002) Annual report, Director General Health, 2001-2002 Government of Pakistan.

14. Wasim J, Nadim J, Javed Y, Muhammad I, Syed FAT , Tazeen J, Saeed A, Saeed H, Hasnain AS, Sheikh QN (2006) Hepatitis B and C: prevalence and risk factors associated with seropositivity among children in Karachi, Pakistan. J BMC InfectiousDiseases. Available: http://www.ncbi.nlm.nih.gov/pmc/articles/PMC1539007/?to ol=pubmed. Accessed 08 April 2010.

15. Ahmad K (2004) Pakistan: a cirrhotic state? Lancet 364: 1843-1844.

16. Khan AJ (2000) Unsafe injections and the transmission of hepatitis B and C in a Periurban community in Pakistan. Bull World Health Organ 78: 956-963.

\section{Corresponding Author}

Muhammad Ayaz Mustufa

5 th floor

National Institute of Child Health (NICH)

PMRC Specialized Research Center on Child Health

Rafeequi Shaheed Road Karachi, Pakistan

Telephone: +92 021 9201261, Ext. no. 242

Email: a_m_bukero@yahoo.com

Conflict of interests: No conflict of interests is declared. 